\title{
Performance of West African Dwarf (Wad) Goats Fed Dietary Levels of Boiled Rubber Seed Meal (Hevea Brasiliensis)
}

\author{
Metiabasi D Udo $^{1 *}$, F O Ahamefule ${ }^{2}$, JA Ibaewuchi ${ }^{2}$ and Glory D Eyoh ${ }^{1}$ \\ ${ }^{1}$ Department of Animal science, Akwa Ibom State University, Nigeria
}

${ }^{2}$ Department of Animal Production and Livestock Management, Nigeria

Received: 眥 September 18, 2018; Published: 眥 September 25, 2018

*Corresponding author: Metiabasi D Udo, Department of Animal science, Akwa Ibom State University, Uyo, Nigeria

\begin{abstract}
Effect of boiled rubber seed meal (BRSM) based diets on the performance of West African Dwarf (WAD) bucks was investigated. Four groups of WADS were randomly fed with the 4 experimental diets (A-D) formulated to contain 0, 10, 20 and $30 \%$ BRSM. The experiment lasted for 56 days. Average daily feed intake (g) were 417.90; 428.93; 322.00 and 288.10 for diets A, B, C, D, and the corresponding average daily weight gain was $31.69,53.92,46.62$, and 34.64 respectively. Feed/gain ratio was 6.90 for goats fed diet $\mathrm{C}$ and 7.95 for those fed with diet B. Feed cost per Kg weight gain was N 115.29 for diet C and N 120.42 for diet B. The warm carcass and dressing \% were insignificant among the 4 treatment groups, but goats fed diet $\mathrm{C}$ showed superiority. Legs, shoulder, sets and bone to lean ratio differed significantly between the treatment groups.
\end{abstract}

Keywords: Conventional; Non-Conventional; Rubber Seed; West African Dwarf Goats

\section{Introduction}

The economic depression of nations has greatly reduced meat availability, and the inadequacy of meat supply has been aggravated by a combination of environment, feed and management factors Wikipedia, [1], Udo [2]. In recent years many categories of Nigerian farmers tend to invest in ruminant livestock farming Hoffmann [3] yet cost of conventional feeds still posed big challenge Hassan [4]. Feed as reported by Akpodiete and Inoni [5], accounts for 60 $70 \%$ of total cost of livestock production and that it's inadequacy in quality and quantity could lead to a situation of low nutritional status, poor weight gain, poor reproductive ability, poor production, poor health condition and poor conversion ratio Fajemisin [6]. It therefore, becomes important to supply adequate feed in quantity and quality for optimal performance by livestock. Goats' farming offers ample opportunity for meat inclement and availability. They are easy to keep, require smaller capital investment, play significant role in socio-economic life of the people as they contribute about $35 \%$ Nigerian meat supply Oloche [7], and provides income to farmers Peacock [8]. West African dwarf goats are the prevalent and trypono-tolerant breed in the derived and guinea savannah zones Eroarome [9], Udo [10]. But it is worrisome that lack of government legislation for the multiplication of this hardy breed, nutritional constraint particularly during the dry season coupled with the extensive mode of production posed serious problem to their production in the tropic Ahamefule [11] and Ahamefule and Udo [12]. To address the nutritional need of goats, it is therefore, important to supplement their diet with concentrate. As a result of high cost conventional feedstuff and in attempt to reduce competition between man and livestock, nutritionists are in search for alternative non-conventional feedstuff that are cheap and readily available Ahamefule and Udo [12]. There are huge naturally occurring non-conventional feedstuffs that can profitably be used to stimulate small ruminant production Udo [2], Udo [10]. Prominent among them is rubber seed which has no feed value for human Udo [10]. The Humid tropics has large acreage of rubber plantation, and in Nigeria it is cultivated on estimated 185,000 hectares with seed collection of about 10,175 tonnes/year Udo [2], with crude protein content range of $21-28 \%$, Crude fibre range of $4.47-8 \%$ (Udo [2], Udo [10], Njwe [13] and energy range of 2.32 - 2.58 MJ/Kg Udo [2]. Several works on rubber seed have been reported for some breeds animal: pigs Babatunde [14], poultry Nouke and Endeley, 2001, 
sheep Njwe [13]; but there is paucity of information on the feeding of rubber seed to West African Dwarf Goats. This work however, was designed to evaluate the performance of West African dwarf goat fed dietary levels of rubber seed meal based diet.

\section{Materials and Methods}

\section{Experimental Site}

The study was conducted at the Goat unit of the Teaching and Research farm, Akwa Ibom State University, Obio Akpa campus, Akwa Ibom State, Nigeria. Obio Akpa is located between longitudes $7^{\circ} 27^{\prime} \mathrm{E}$ and $7^{\circ} 58^{\prime} \mathrm{E}$. It is located within $3500-5000 \mathrm{~mm}$ annual rainfall with average monthly temperature of $25^{\circ} \mathrm{C}$

\section{Animal Management}

Sixteen (16) weaners West African Dwarf (WAD) bucks of 6-7 months old were procured from farmers in the University environment and used for the investigation. On the fifth day of arrival, these animals were all dewormed using albendazole thiabendazole. They were subsequently given acaricide birth using asuntol solution and after that quarantined for 21 days and fed forage and supplements of the test diet for acclimatization. They were vaccinated against Pestes des petite ruminant (PPR) using Rinder pest Tissue culture vaccine. The goats were randomly divided into four groups of four goats per treatment and housed individually in well ventilated cement floored pens equipped with feeders and drinkers.

\section{Experimental Design/Procedures}

Four diets were formulated to contain $0-30 \%$ boiled rubber seed meal (BRSM) and designated as A, B, C and D. These diets were assigned randomly to the four animal groups in a completely randomised design. Each goat received $1 \mathrm{~kg}$ of designated diet in addition to $2 \mathrm{Kg}$ of guinea grass (Panicum maximum). Daily feed intake was determined by subtracting daily feed refusal from the $1 \mathrm{~kg}$ given the previous day. These were used to calculate the average daily feed intake, average daily weight gain feed conversion ratio, and feed economics of production for each treatment group.

\section{Experimental Diets}

Four (4) experimental diets (A-D) were formulated to contain various inclusion levels (0-30\%) of boiled rubber seed meal (BRSM) with other conventional ingredients as shown in (Table 1).

\section{Processing of Rubber Seed}

Twenty (20) kilogrammes of raw rubber seeds were introduced into cooking pot (in batches) whose water has attained boiling temperature $\left(100{ }^{\circ} \mathrm{C}\right)$ and allowed to boil for 30 minutes after which the seeds were decanted. The boiled seeds were sun-dried for seven (7) days, then dehulled and nuts milled, pressed using garri processing machine to remove oil and the products used to formulate boiled rubber seed meal-based diet (BRSM).

\section{Slaughter Technique}

At the end of the feeding trail, three goats per treatment group were starved for 24 hours prior to slaughter. Each goat was weighed before slaughter, after bleeding and after dressing. Dressing percentages were calculated as the weight of dressed warm carcass in relation to the live weight before slaughter. The dressed warm carcass is defined as the weight of the goat after the removal of the head, skin, content of the thoracic, limbs, distal to the carpal and tarsal joints and pelvic cavities (including the diaphragm and kidney). The lungs, head, heart, liver, limb (four feet) and skin were weighed also.

\section{Carcass Evaluation}

Three animals per treatment group were slaughtered for carcass evaluation. Jointing of carcass (meat cut) was done following the method adopted by Ahamefule [11]. Each dressed warm carcass was divided down the spinal cord by means of meat saws into two (2) equal half and weighed individually. The left half was subsequently divided into various cuts consisting of thigh, shoulder, loin, sets and ends. Each of the cuts was weighed and the weight doubled in each case before expressing it as percentage of the dressed carcass. The leg (thigh) was severed at the attachment of the femur to the acetabulium; the loin consists of the lumber region plus a pair of ribs, the ends (spare ribs plus belly) consist of six (6) abdominal ribs, the shoulder consist of the scapular, and the sets made up of the breast and the neck. The loin cuts were then dissected into muscles and bone with ligament to obtain the meat to bone ratio.

\section{tatistical Analysis}

The experiment was laid out as completely Randomized design. All data were analysed in a one -way analysis of variance (ANOVA) using SPSS [15] package. Duncan's Multiple Range Test Duncan [16] was used to separate significant means.

\section{Chemical Analysis}

All feed samples were analysed for proximate composition using AOAC (2007).

\section{Results and Discussion}

The composition and proximate assay of the experimental diets formulated to contain 0-30\% boiled rubber seed meal (BRSM) are presented in (Table 1). The dry matter (DM) content of the diets, save for ration B (10\% BRS), were fairly comparable (Table 2$)$. The crude protein (CP) ranged from $14.06-15.82 \%$ and increased as inclusion levels of BRSM increased from B-D. Crude fibre (\%) (CF) followed a reverse trend of the CP values. The ether extract (EE) composition (\%) increased from diets A-D and stabilized in C and D. the ash contents (\%) of the diets followed similar pattern as the EE, rising and stabilizing as the case was. Nitrogen free extract (NFE) values (\%) rose from $\mathrm{A}-\mathrm{B}$ and subsequently decline in diets $\mathrm{C}$ and $\mathrm{D}$. 
The energy values (Kcal/g) followed similar trend as NFE. CP and energy content of the four diets were all above what is required by WAD goats as reported by Ahamefule [11], Akinsonyinu [17].

Table 1: Proximate composition of experimental diets containing various levels of boiled rubber (Hevea brasiliensis) seed meal.

\begin{tabular}{|c|c|c|c|c|}
\hline \multicolumn{5}{|c|}{ DIETS } \\
\hline Ingredients & A & B & C & D \\
\hline Cassava peels & 30.5 & 30.5 & 30.5 & 30.5 \\
\hline BRSM & 0 & 10 & 20 & 30 \\
\hline $\begin{array}{c}\text { Brewer dried } \\
\text { grain }\end{array}$ & 50 & 40 & 30 & 20 \\
\hline Palm kernel cake & 17 & 17 & 17 & 17 \\
\hline Bone Meal & 2 & 2 & 2 & 2 \\
\hline Salt & 0.5 & 0.5 & 0.5 & 0.5 \\
\hline Total & 100 & 100 & 100 & 100 \\
\hline
\end{tabular}

Table 2: Chemical assay of experimental diets containing various levels of boiled rubber (Hevea brasiliensis) seed meal (\%DM).

\begin{tabular}{|c|c|c|c|c|}
\hline Dry matter & $\mathbf{8 9 . 8}$ & $\mathbf{9 1 . 9 6}$ & $\mathbf{8 8 . 2 7}$ & $\mathbf{8 7 . 0 2}$ \\
\hline Crude protein & 14.5 & 14.06 & 15.4 & 15.82 \\
\hline Crude fibre & 18.12 & 17.65 & 17.07 & 16.82 \\
\hline Ether extract & 4.1 & 4.9 & 4.92 & 4.92 \\
\hline Ash & 5.94 & 6.26 & 6.37 & 6.73 \\
\hline N- Free extract & 47.44 & 47.59 & 44.49 & 42.73 \\
\hline GE (Kcal/g)* & 1.68 & 1.77 & 1.66 & 1.64 \\
\hline Total & 100 & 100 & 100 & 100 \\
\hline
\end{tabular}

*Calculated, BRSM= Boiled rubber seed meal.

\section{Response of West African Dwarf (WAD) Goats}

The performance of WAD goats fed various inclusion level of boiled rubber seed meal (BRSM) is shown in Table 3. Goats fed 10\% BRSM consumed significantly $(\mathrm{P}<0.05)$ more feed $(428.93 \mathrm{~g} / \mathrm{d})$ than goats fed diets containing $0 \%(417.90 \mathrm{~g} / \mathrm{d}), 20 \%(322.00 \mathrm{~g} / \mathrm{d})$ and $30 \%(288.04 \mathrm{~g} / \mathrm{d}$ ) BRSM. Goats fed diet A (Control) had similar intake $(\mathrm{P}>0.05)$ with goats fed 10\% BRSM diet; their values were significantly different $(\mathrm{P}<0.05)$ with the feed intake of goats fed diets $C$ and $D$. This may be due to the increasing levels of rubber seed meal from B-D which Gohl [18] reported that rubber seed is not quite palatable and appetizing to ruminant. However, the values obtained in this report is in consonance with previous reports by Spring [19] that feed intake and growth decreased as rubber seed meal (RSM) incorporation levels increased in poultry rations. Njwe [13] also reported that rubber seed is not quite appetizing to sheep and that RSM should not exceed 20\% level incorporation and not more than $10 \%$ for poultry Babatunde [19] while Devendra [20] considered $20 \%$ as optimal inclusion level for pigs. The trend of intake in this study agrees with the report by Rajan [21] that weight gain was not affected when fed diet containing 20\% BRSM, but subsequently, a linear decrease in feed intake and daily weight gain occurred as the incorporation of BRSM exceeds $20 \%$. The feed gain ratio for goats fed 20\% BRSM was least (6.90) and apparently best and was in line with the reports Njwe [13], Rajan [21] that small ruminants can utilize up to $20 \%$ rubber seed without adverse effect on performance. The average daily weight gain range of $34.64-$ 53.92g obtained in this study compared favourably with the range reported for WAD goats within the first 12 months of life Nuru [22], Anya [23].

Table 3: Performance of WAD Goats Fed Experimental Diets Containing Various Levels of Boiled Rubber (Hevea brasiliensis) Seed Meal.

\begin{tabular}{|c|c|c|c|c|c|}
\hline Parameter & A & B & C & D & SEM \\
\hline $\begin{array}{c}\text { Initial mean wt } \\
(\mathrm{Kg})\end{array}$ & 6.83 & 6.63 & 6.58 & 6.5 & 0.367 \\
\hline $\begin{array}{c}\text { Final mean wt } \\
(\mathrm{Kg})\end{array}$ & 8.94 & 9.65 & 9.19 & 8.44 & 0.555 \\
\hline $\begin{array}{c}\text { Total feed intake } \\
(\mathrm{Kg})\end{array}$ & $23.40^{\mathrm{a}}$ & $24.02^{\mathrm{a}}$ & $18.03^{\mathrm{b}}$ & $16.13^{\mathrm{b}}$ & 1.294 \\
\hline $\begin{array}{c}\text { Daily feed intake } \\
\text { (g|d) }\end{array}$ & $417.90^{\mathrm{a}}$ & $428.93^{\mathrm{a}}$ & $322.00^{\mathrm{b}}$ & $288.10^{\mathrm{b}}$ & 19.096 \\
\hline $\begin{array}{c}\text { Total weight gain } \\
(\mathrm{Kg})\end{array}$ & $2.11^{\mathrm{b}}$ & $3.02^{\mathrm{a}}$ & $2.61^{\mathrm{b}}$ & $1.94^{\mathrm{c}}$ & 0.103 \\
\hline $\begin{array}{c}\text { Ave.Daily weight } \\
\text { gain (g) }\end{array}$ & $37.69^{\mathrm{c}}$ & $53.92^{\mathrm{a}}$ & $46.62^{\mathrm{b}}$ & $34.64^{\mathrm{c}}$ & 1.679 \\
\hline Feed/gain ratio & $11.09^{\mathrm{a}}$ & $7.95^{\mathrm{c}}$ & $6.90^{\mathrm{c}}$ & $8.31^{\mathrm{b}}$ & 1.451 \\
\hline
\end{tabular}

$a, b, c$ Means on the same row with superscripts differ significantly $(\mathrm{P}<0.05)$.

\section{Feed Economy}

Table 4: Feed economies of WAD goats fed various inclusion levels of boiled rubber seed meal-based diets.

\begin{tabular}{|c|c|c|c|c|}
\hline \multicolumn{5}{|c|}{ DIETS } \\
\hline Cost (N) & A & B & C & D \\
\hline $\begin{array}{c}\text { Cost/100kg diet } \\
\text { (N) }\end{array}$ & 1359 & 1514 & 1669 & 1824 \\
\hline Cost/kg (N) & 13.59 & 15.14 & 16.69 & 18.24 \\
\hline $\begin{array}{c}\text { Total feed } \\
\text { consumed (kg) }\end{array}$ & 23.4 & 24.02 & 18.03 & 16.1 \\
\hline $\begin{array}{c}\text { Total cost of feed } \\
\text { (N) }\end{array}$ & 318.01 & 363.66 & 300.92 & 294.21 \\
\hline $\begin{array}{c}\text { Initial mean } \\
\text { weight (kg) }\end{array}$ & 6.83 & 6.63 & 6.58 & 6.5 \\
\hline $\begin{array}{c}\text { Final mean weight } \\
\text { (kg) }\end{array}$ & 8.94 & 9.65 & 9.19 & 8.44 \\
\hline \begin{tabular}{c} 
Weight gain (kg) \\
\hline $\begin{array}{c}\text { Feed cost/kg } \\
\text { weight gain (N) }\end{array}$
\end{tabular} & 150.71 & 120.42 & 115.29 & 151 \\
\hline
\end{tabular}

The economy of feeding WAD goats with various inclusion levels of boiled rubber seed meal (BRSM) is presented in Table 4. Daily feed consumed by animals in treatment A and B were similar, but the two groups differed significantly $(\mathrm{P}<0.05)$ from animals fed diets $\mathrm{C}$ and $\mathrm{D}$ that were also similar in their feed intake. Goats fed diet B (10\% BRSM) supported highest daily weight gain followed 
by $20 \%$ and $30 \%$ respectively. The daily weight gain range $(34.64$ - 53.92g/d) reported in this study is lower than the range (35 $65 \mathrm{~g} / \mathrm{d}$ ) reported by Nuru [22] for WAD goats. The feed cost per kilogram weight gain was N150.71 for goats fed diets A of 0\% BRSM. The corresponding values for animals fed diets B, C and D were N120.42, N115.29 and N151.65 respectively. The result obtained in this study followed the findings trend of similar investigations by Ahamefule [11] and Anya [23]. They also reported superior feed cost per kilogramme weight gain for WAD goats fed diets containing $20 \%$ Pigeon pea and African yam bean respectively. For best yield returns on investment, incorporation of 20\% BRSM in WAD goat's diet is advisable.

\section{Carcass Characteristics}

Table 5 shows the carcass yield of WAD goats fed graded levels of diets. The superior warm carcass value $(4.09 \mathrm{Kg})$ obtained for goats fed $20 \%$ BRSM was not significantly $(\mathrm{P}<0.05)$ different from the values of $3.40 \mathrm{Kg}, 3.67 \mathrm{Kg}$ and $2.84 \mathrm{Kg}$ recorded for goats fed $0 \%$, $10 \%$ and $30 \%$ BRSM respectively. More so, there was no significant different $(\mathrm{P}<0.05)$ in their dressing percent, though goats fed diet C (20\% BRSM) has a superior value of 45.40 . The range of dressing percent (DP) obtained in this study $(37.22$ - 45.40) was comparable with the values (33.05 - 58.07) reported by Udo and Nuru (1985) 45 - 52\% for WAD goats in different feeding trials. In Table 6 significant differences $(\mathrm{P}<0.005)$ only occur among treatment groups for leg, shoulder, sets and bone to lean ratio. The leg meat cut (g) was best for goats fed diet C (1115.40) and was not significantly different $(\mathrm{P}<0.05)$ from goats fed diet $\mathrm{B}(1030.30)$, but however differed $(\mathrm{P}<0.05)$ significantly from values for goats fed diets A (875.00) and D (525.00). In the shoulder cut (g), goats fed diet $C$ had best cut $(1030.30)$ which also differed $(\mathrm{P}<0.05)$ significantly from corresponding values obtained for goats fed diets A (803.10), B (926.90) and D (510.00) Goats fed 20\% BRSM (C) diet had sets value $(650.00 \mathrm{~g})$ which was superior $(\mathrm{P}<0.05)$ to other treatment groups. In all parameters investigated goats fed BRSM yielded superior meat cuts relative to other treatment groups indicating that it was best utilized of all the diets. The relatively high but comparable bone to lean ratio obtained for goats fed $0 \%$ and 30\% BRSM diets in this study is an indication of high feed conversion efficiency by goats in group C (20\% BRSM). This is also confirmed by the superior dressing percent (45.40\%) and lowest (6.90) feed conversion ratio of goats fed 20\% BRSM diet. The mean organ weight for the different group of goats fed the BRSM diets in Table 4-6 shows that all the organs (Liver, Kidney, Heart, Lungs and Spleens) weights were similar $(\mathrm{P}<0.05)$; they were not affected by the dietary treatments. Proving that all the inclusion levels of BRSM were safe as dietary concentrate for WAD goats but 20\% BRSM diet gave outstanding performance in feed gain ratio, daily weight gain, dressing percent, meat cuts (leg, Shoulder, loin, sets, ends) and bone to lean ratio of WAD goats. Therefore for goat's production/ fattening programmes, $20 \%$ inclusion level of boiled rubber seed meal is recommended as it also produced the cheapest cost per. kilogramme weight gain. This study has shown that if WAD goats are given right nutrition, sixty days could be used to fatten them to market weight, therefore making it possible for a farmer to carry out fattening programmes up to 6 times in a year. Thus generating good income for the farmer.

Table 5: Carcass yield of West Africa dwarf goats fed various levels of boiled rubber (Hevea brasiliensis) seed meal-based diets.

\begin{tabular}{|c|c|c|c|c|c|}
\hline \multicolumn{6}{|c|}{ DIETS } \\
\hline Parameter & A & B & C & D & SEM \\
\hline $\begin{array}{l}\text { Live weight } \\
\text { (kg) }\end{array}$ & 8.5 & 8.44 & 8.97 & 7.65 & 0.78 \\
\hline $\begin{array}{l}\text { Empty live } \\
\text { wt (kg) }\end{array}$ & 5.53 & 5.4 & 5.77 & 4.63 & 0.63 \\
\hline $\begin{array}{l}\text { Warm } \\
\text { carcass } \\
(\mathrm{kg})\end{array}$ & 3.4 & 3.67 & 4.09 & 2.84 & 0.45 \\
\hline Dressing \% & 39.86 & 43.36 & 45.4 & 37.22 & 2.16 \\
\hline Leg (g) & $875.00^{\mathrm{b}}$ & $1030.30^{\mathrm{a}}$ & $1115.40^{\mathrm{a}}$ & $525.00^{c}$ & 80.96 \\
\hline $\begin{array}{l}\text { Shoulder } \\
\text { (g) }\end{array}$ & $803.10^{c}$ & $926.90^{\mathrm{b}}$ & $1030.30^{\mathrm{a}}$ & $510.00^{d}$ & 19.9 \\
\hline Loin (g) & 600 & 623.6 & 661.5 & 495.1 & 98.31 \\
\hline Sets (g) & $421.8^{\mathrm{b}}$ & $427.3^{b}$ & $650.00^{\mathrm{a}}$ & $290.30^{c}$ & 54.94 \\
\hline Ends (g) & 402.7 & 432.9 & 625.2 & 450 & 64.65 \\
\hline $\begin{array}{l}\text { Abdominal } \\
\text { fat (g) }\end{array}$ & 159.7 & 167.4 & 148.1 & 125 & 14.33 \\
\hline $\begin{array}{c}\text { Bone to } \\
\text { lean ratio } \\
\text { (g) }\end{array}$ & $0.26^{\mathrm{a}}$ & $0.23^{\mathrm{b}}$ & $0.21^{\mathrm{b}}$ & $0.27^{\mathrm{a}}$ & 0.03 \\
\hline Head (g) & 616.14 & 709 & 662.5 & 600.37 & 63.12 \\
\hline Skin (g) & 615.39 & 616.64 & 625 & 536.97 & 59.28 \\
\hline Feet (g) & 210 & 210 & 250 & 200 & 25.98 \\
\hline Liver (g) & 155 & 153.5 & 137.5 & 147.5 & 20.91 \\
\hline Kidney (g) & 20 & 26 & 31.5 & 25 & 7.47 \\
\hline Heart (g) & 15 & 38.5 & 28.5 & 30 & 9.74 \\
\hline Spleen & 11 & 16.5 & 10 & 7.5 & 3.33 \\
\hline $\begin{array}{c}\text { Diaphragm } \\
(\mathrm{g})\end{array}$ & 50 & 50 & 43 & 45 & 2.75 \\
\hline $\begin{array}{l}\text { Full gut } \\
(\mathrm{kg})\end{array}$ & 2.712 & 2.89 & 2.73 & 2.46 & 0.26 \\
\hline $\begin{array}{c}\text { Empty gut } \\
\text { (g) }\end{array}$ & 812.5 & 757.5 & 850 & 652.5 & 75.52 \\
\hline Tail (g) & 15 & 14 & 11 & 10 & 3.93 \\
\hline Lungs (g) & 77.5 & 88.18 & 77.5 & 87.5 & 7.47 \\
\hline
\end{tabular}

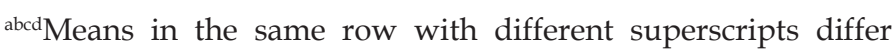
significantly $(\mathrm{P}<0.05)$. 
Table 6: Average weight of meat cuts, organs and offal weights expressed as percentages of warm carcass or empty live weight.

\begin{tabular}{|c|c|c|c|c|}
\hline \multicolumn{5}{|c|}{ Meat Cuts as Percentage of Warm Weight } \\
\hline $\begin{array}{c}\text { Warm } \\
\text { weight }\end{array}$ & 3406 & 3675 & 4091 & 2845 \\
\hline Leg & 25.69 & 28.04 & 27.26 & 18.45 \\
\hline Shoulder & 23.58 & 25.22 & 25.18 & 17.93 \\
\hline Loin & 16.97 & 16.17 & 17.62 & 17.41 \\
\hline Sets & 11.63 & 12.38 & 15.89 & 10.2 \\
\hline Ends & 11.78 & 11.82 & 15.28 & 15.82 \\
\hline \multicolumn{5}{|c|}{ Offal as percentage of empty live weight } \\
\hline Head & 11.4 & 12.27 & 11.97 & 12.95 \\
\hline Skin & 11.38 & 10.68 & 11.3 & 11.58 \\
\hline Feet & 3.88 & 3.64 & 4.52 & 4.31 \\
\hline Emptygut & 15.03 & 13.11 & 15.36 & 14.07 \\
\hline \multicolumn{5}{|c|}{ Organs as percentage of empty live weight } \\
\hline Liver & 2.87 & 2.66 & 2.49 & 3.18 \\
\hline Kidney & 0.37 & 0.45 & 0.57 & 0.54 \\
\hline Heart & 0.28 & 0.67 & 0.52 & 0.65 \\
\hline Lungs & 1.43 & 1.53 & 1.4 & 1.89 \\
\hline Spleen & 0.2 & 0.29 & 0.18 & 0.16 \\
\hline
\end{tabular}

\section{Conclusion}

This study revealed that boiled rubber seed meal generally enhanced performance at different level (10-30\% BRSM) with all the inclusion levels being safe as dietary supplement for WAD goats. However, 20\% BRSM inclusion level gave the best performance, and is therefore recommended for goat's production/fattening programme as it also produced the cheapest cost per kilogramme weight gain.

\section{References}

1. Wikipedia (2011) The free Encydopedia.

2. Udo MD (2015) Evaluation of rubber seed meal-based diets for West African Dwarf Goat Production in the Humid Tropics. Thesis, Micheal Okpara University of Agriculture, Umidike, Abia State Nigeria.

3. Hoffman I (2002) Crop - Livestock interactions and soil fertility management in northwest Nigeria. First Global conf. On Organic Beef cattle Production.

4. Hassan MR, Abdu SB Amodu, Tamburawa MS, Abubakar SA (2015) Effect of seed and Irrigation Frequency on Growth and Forage Yield of Centro (Centrosema pescuorum mart. Ex Bent). Proc $40^{\text {th }}$ Ann Cont Nig Society for Ani Prod pp. 460-463.

5. OJ Akpodiete, Inoni OE (2000) Economics of production of broiler chickens fed maggot meals as replacement of fish meal: Nigerian Journal of Animal Production 27: 59-63.

6. Fajemisin AN, Omotoso OB, Ayelotan TA (2015) Sepium and Acacia nilotica tomentosa. Proc $40^{\text {th }}$ Anu Conf Nigerian Society for Animal Prod pp. 468-471.

7. Oloche J, Oluremi OIA, Shaapera SS (2015) Proc. 40th Ann Conf Nigerian Scociety for Animal Prod. $15^{\text {th }}-19^{\text {th }}$ March 2015, NAPRIL/ABU, Zaria, Nigeria, pp. 488-490.

8. Peacock C, Devendra C, Ahuya C, Roets M, Hossian M (2005) Goats In: Owen E, Kitalyi A, Jayasuriya N, Smith T (Eds). Livestock and Wealth Creation: Improving the husbandry of animals kept by resource - poor people in developing countries. Nottingham University Press, United Kingdom, pp. 361-385.

9. Eroarame M A (2006) Nigeria: Country Pasture/Forage Resource Profile. A documentary on Soil, Crop and Animal Science Resource of Nigeria.

10. Udo M D, Ekpo U Ahamefule F O (2016) Effect of Processing on the Nutrient Composition of Rubber seed meal. Journal of Saudi Society of Agricultural Sciences 17(3): 297-301.

11. Ahamefule FO (2005) Production in South-Eastern Nigeria. Ph.D. Thesis. College of Animal Science and Animal production.

12. Ahamefule FO, Udo (2010) Performance of West African Dwarf (WAD) Goats Fed Raw or Processed Pigeon pea (Cajanus cajan) seed mealbased diets. Nig Journal of Anim Prod 32(2): 227-236.

13. Njwe RM, Chifon MK, Ntep R (1988) Potential of Rubber seed as Protein concentrate supplement for Dwarf sheep of Cameroun. Proc. Of the first joint workshop: Trypanotolerant livestock in West and Central Africa. Vol. 2 Malawi: Fao Corporate Document Repository.

14.SPSS (1999) Statistical package for Social Science. Procedures and Facilities for Release. McGrow - Hill Books Co. NY.

15. Duncan DB (1955) New multiple Range and multiple F Test. Biometrics 11(1): 1-42.

16. Akinsoyinu AO, C F I Onwuka (1974) Studies on protein and energy utilizations by the West African dwarf goats:Ph.D. Thesis, University of Ibandan Nigeria 2(4): 127-181.

17. Gohl B (1998) Tropical feds. FAO, Rome, Italy.

18. Spring (2004) War on weeds. Rails to trails magazine.

19. Babatunde GM, Pond WG, Peo ER (1990) Nutritive Value of rubber seed (Hevea brasiliensis) meal: Utilization by growing pigs of semipurified Diets in which rubber seed meal partially replaced soybean meal.

20. Devendra C (1981) Non-Conventional feed resources in Asia and Far East.APHCA pub.2, FAO Bangkok.

21. Rajan A, Sneekumaran T, JA Mammel, V Vijayakumar (1990) An assessment of the goitrogenic effect of rubber seed cake. Ind J Mof Animal Sci 60(8): 995- 997.

22. Nuru S (1985) Trends in small ruminant production in Nigeria. In: Small Ruminant Production in Nigeria Adu IF, Osinowo OA, Taiwo BBA and Alhassan, WS (Eds). Proceedings of the National Conference on Small Ruminant Production, Zaria, Nigeria, pp. 35-51.

23. Anya MI (2012) Evaluation of African Yam bean-Cassava peel meal based diets for goat's production in south-eastern Nigerian. Thesis, Michael Okpara University of Agriculture 5(7): 95-108. 


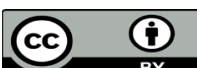

This work is licensed under Creative Commons Attribution 4.0 License

To Submit Your Article Click Here: Submit Article

DOI: 10.32474/CIACR.2018.04.000198

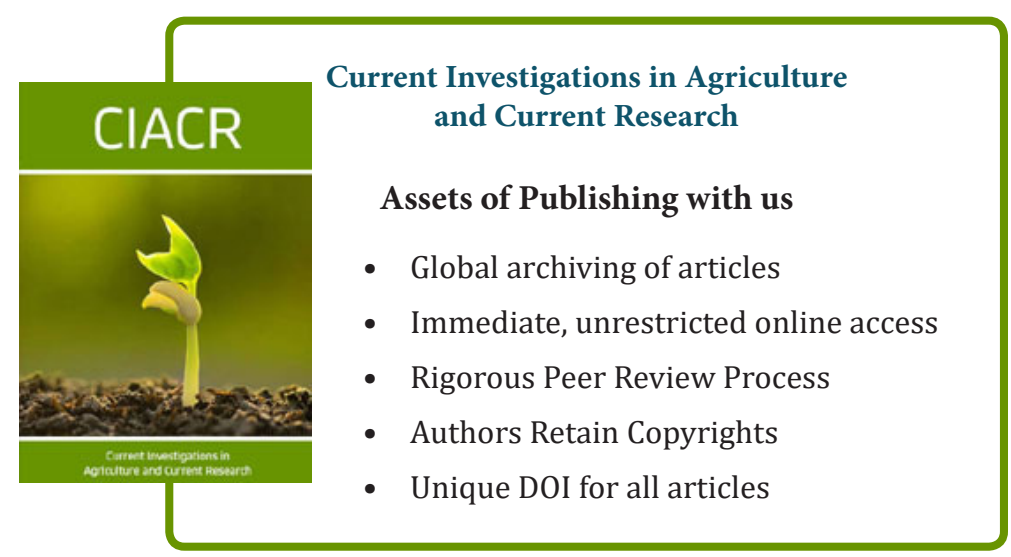

